\title{
Early Catholicism and the organisational structure of the United Methodist Church in Zimbabwe
}

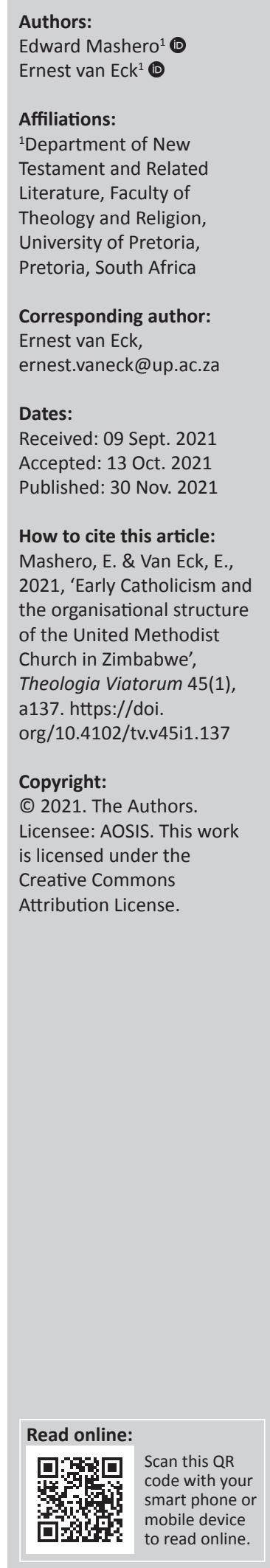

The organisational structure of the United Methodist church shares many features with the early catholic institutions. Increased institutionalisation, that is, authority connected with office, is the clearest sign of Early Catholicism. By the late first century, the titles of bishop

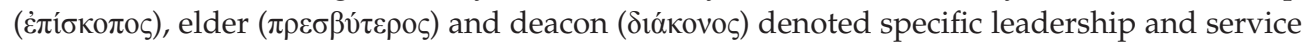
functions in the church. This study stresses the ethical qualifications and diaconal duties of these office bearers, applying it to the duties and responsibilities of United Methodist pastors, district superintendents, bishops and laity. It is argued that candidates for ordination should be aware of their calling to the divine ministry and their calling should be authenticated and recognised without a test of authenticity by the Church. In the Early Catholicism period, qualified leadership was established to preserve faith and combat false teaching. This must also be the case in the United Methodist Church.

Keywords: early Catholicism; bishop; laity; pastor; clergy; United Methodist; institution; organisational structure; doctrine.

\section{Introduction}

This article investigates the influence of Early Catholic institutions upon the organisational structure of the United Methodist Church in Zimbabwe. It provides the responsibilities of bishops, elders, deacons and presbyters in the early Catholic Church. Bishops were the custodians of faith; they guarded against false teaching or heresy. They were concerned with preserving sound doctrine and also guarded the deposit of faith (Puskas 1989:240). The fixed organisational structure was established as a defence against Gnosticism and Montanism. The United Methodist bishops, pastors and superintendents are the chief administrators of the church. Pastors perform the fourfold ministry of the word, order, service and sacrament. According to Puskas (1989:241) 'Pastors uphold the social principles of the church, namely the natural world, the nurturing community, the social community, the economic community, political community and the world community'. These social principles can be traced back to John Wesley who is the founder of Methodism. Wesley is well known for his three moral principles, namely do good, do no harm and stay in love with God.

\section{Fixed organisational structure in Early Catholicism}

In order to guard against false teachings such as Gnosticism and Montanism, the early church established institutions with qualified leadership. According to Dunn (1990:351), 'authority becomes coterminous with office, a basic distinction between clergy and laity becomes evident'. God's grace becomes progressively narrowed to well-structured rites. The major feature in the organisational structure of emerging orthodoxy was that leadership should derive its authority from the office rather than charisma or personal ability. In earliest Christian worship, leaders often derived their authority from endowments of the spirit and special abilities (1 Cor 12:8-10; Rm 12:3-8). Assistants and overseers also emerged (Phlp 1:1), but their responsibilities were not well defined (Puskas 1989:239).

By the late first century, the titles bishop, elder and deacon signified defined service and leadership function in the church. These officials often concurred with more ecstatic itinerant teachers and prophets. By the second century, certain organisational developments emerged. The doctrinal duties and ethical qualifications of the office bearers were highlighted, even though the pastorals made no clear distinction between elder and bishop. They were to be the role models for the church and to safeguard the apostolic teaching against heresy. The letters of Ignatius distinguished the office of the elder from bishop and emphasised the superiority of the bishop in a hierarchical order. Therefore, in the writings of Ignatius of Antioch the organisational propensity to attribute 
authority to the office independent of charisma and personal ability became a vital force. The following texts from the pastorals emphasise the general responsibilities and moral qualifications for offices of elder, bishop and deacon (Dibelius \& Conzelmann 1776:159). These contain the general ethical conducts and virtues expected of public officials, bishops (1 Tm 3:1-7; Tm 7:7-9) elder (1 Tm 4:14; 5:17-20; 1 Pt 5:1-4; Ac 20:17) deacon (1 Tm 3:8-10; Phlp 1:1; Rm 16:1). In 1 Timothy 5:17-18 elders are described as engaging in the ventures assigned to the bishops (1 Tm 3:1-7; Tm 1:7-9). These activities are preaching, teaching and governing. Also in Titus 1:5-7, the titles bishops and elder are interchangeably used. The pastors also presume a council of elders in the congregation (1 Tm 4:14). However, the essence of their leadership responsibility is vague and obscure. The obtaining of leadership authority seems to be managed by the orthodox leadership. Potential leaders are tried and tested before being endorsed into office (1 Tm 3:10) (Verner 1983:149).

In the Pastorals the positions of deacons, elders and bishops became well-structured. Important to note is the esteemed positions of Titus and Timothy. These two are not taken as representatives of Paul visiting his churches as ambassadors, just like in the past days (1 Cor 4:17; Phlp 2:19; 1 Th 3:2; 2 Cor $7: 13)$. They began to assume monarchical roles, with power over the community and its members. Timothy and Titus had the responsibility of keeping faith pure (1 Tm 1:3; 4:6). Timothy has authority to enrol a widow and to decline enrolment with no consultation. Timothy had the authority to exert order and dispense justice except to the elders (1 Tm 5:19). He is taken as the court of justice or appellate body, he is above the leadership. Timothy also lays hands and appoints elders (Tt 1:5; 1 Tm 5:22). Clearly, the concept of apostolic succession was now emerging (Dunn 1990:352).

In the Pastorals there is an amalgamation of the office and charisma. In 1 Timothy 4:14 and 2 Timothy 1:6, we notice that the office bearer is acknowledged as having a prophetic gift. This may have been an endeavour to incapacitate the position of false prophets and charismatic leaders who were outside the officialised structure. Only the proficiency for the office is defined in the Pastorals, but certain assertions can be drawn about some duties of elders and bishops. They had Pastoral responsibilities in the community (1 Tm 5:19-20) and they were church representatives to the outside world (1 Tm 3:7) (Verner 1983:151). The office of deacon encompassed deaconesses who were not wives of deacons (1 Tm 3:8-13). The term deaconess was used not in isolation to deacon because there was no feminine term for diakonos. The vital role for the deacon was that of subordinate, perhaps assisting in the works of charity and worship. The encouragements on ministry assume that the elders are already involved in a well-established ministry (Schweitzer 1972:111). In 3 John, we encounter a very influential bishop called Diotrephes who is presented as an opponent of God. He criticises the work of the presbyter and perhaps tried to attain control over the congregation. In 1 Clement, we notice that deacons and bishops were commissioned by apostles and were therefore part and parcel of the divine hierarchical structure. Obedience and compliance with the church officials was therefore enjoined. However, no divergences were realised between presbyters and bishops (Did 15:1-3). The teachers and ecstatic prophets also co-existed with the ministry of deacons and bishops. The correlative regard for both the office bearer and the prophets is also found in the Shepherd of Hermas (Schweitzer 1961:158).

In the letters of Ignatius, we note a comprehensive type of divine authority attributed to the hierarchy of deacons, elders and bishop (Ign 8:1). Even though the relationship of the elders and bishops is close, their offices are well defined and the importance of the bishop over the presbytery or council of elders is evident. In this hierarchical order there are divinely organised offices, the presbytery is the assistant to the bishop whilst the deacon is the assistant to both the presbytery and the bishop. It seems that over each local church and region there was a council of elders and bishops, subordinated by deacons. The bishop perhaps functioned as an administrator, prophet and chief liturgist (Richardson 1970:76). No worship service of any church gathering was authentic without the permission of the presbytery and the bishop. The church must hold on to the bishop as it holds on to Christ and as Christ holds on to the Father (Eph 5:1).

The bishops and presbyters had the responsibility of making sure that sound doctrine was preserved. Through the establishment of fixed organisational structures, the leaders guarded against the deposit of faith (1 Tm 6:20; 2 Tm 1:14). According to Dunn (1990:354): 'It is the transmission of apostolic succession of faith that acts as both the safeguard and standard for sound teachings in emerging orthodoxy'. The succession pattern was established in Christian documents in the first century. Generally, it acquires a certain design that is from Jesus to the apostles then deacons and bishops to safeguard the teachings of the church (Bettenson 1963:24). Paul has been endowed with the gospel of God and endowed the gospel to Timothy (2 Tm 1:13-14). Timothy in turn passed the gospel to faithful men who also taught others. Paul is accorded exceptional eminence in the Pastoral letters (1 $\operatorname{Tm}$ 6:3; $2 \operatorname{Tm} 1: 13)$.

Timothy also has the correspondence of being the apostle's last testament and will for the church. In 2 Peter, Paul and Peter are regarded as authoritarians (2 Pt 3:15-16) and special eminence is accorded to Peter, who is the eyewitness of Jesus' transfiguration. 2 Peter also reads like the last testament and will of the apostle Peter. Luke-Acts has various succession patterns (Puskas 1989:242). In Acts 20:17-38, Paul was appointed by Jesus (Ac 9:22; 26), he commissioned the elders at Ephesus (Ac 28:28-32). In the sermons of Luke-Acts, a continuation of the teaching is observed. From the given transmission of traditional motifs, it is observed that only genuine teachings should be transmitted. The audiences are to take part in the transmission of the tradition to safeguard it. The apostolic succession of faith works both as the model for preserving it and as a standard measurement. 
The course of action of prescribing faith and protecting it is a response to individualistic and visionary groups, such as Gnostics and Montanists. These removed the hierarchical structure and professed to attain their teaching and authority from Jesus via dreams and visions (Malherbe 1986:72). Although wandering charismatics were condoned in the Christian communities, cautions were exercised to avert false teachers or extremists. According to Dunn (1990:349), Luke portrayed the unity amongst Christians by presenting Jerusalem as the fountainhead of worship.

\section{Duties and responsibilities of pastors in the United Methodist Church}

According to Patterson (1990:267), 'a pastor is an ordained elder, licensed person or a provisional deacon accredited through voting by clergy members'. He or she is commissioned by a resident bishop to take charge of a parish. The responsibilities of elders are obtained from the authority given in ordination. These responsibilities are enshrined in the fourfold ministry of order, service, word and sacrament. Pastors are sanctioned to teach, to preach, to administer sacraments, to counsel, offer pastoral care and to be chief administrator in the church.

A pastor in the United Methodist Church performs ecclesial acts and preaches the word of God. He or she also leads in worship and in engaging congregants into bible study.

According to Patterson (1990:269), it is the responsibility of the pastor to be involved in the truthful conveyance of the Christian doctrine. The pastor participates by leading people in evangelistic outreaches and disciple making processes and encouraging members to guard against the deposit of faith. He or she gives pastoral guidance, supports and trains laity leadership, furnishing them to fulfil their missionary tasks. The pastors give general oversight to the Christian educational programmes and to encourage members to constantly use the United Methodist media and literature. The pastor is responsible for setting the aims and objectives, plan of action and evaluation. The pastors also manage the worldly events of the parish in their appointments (Kirby 2000:33). It is also the responsibility of the pastor to administer the amenities of the constitution. They promote and model the stewardship of giving and teach members to embrace giving as a biblical principle. Pastors take care of all church records, which include financial, membership and properties. Pastors lead the church in racial and ethnic support programmes.

It is the responsibility of the pastor to counsel members about ethical, personal or spiritual attacks. They have the responsibility of conducting burial services and solemnising marriages. Pastors solemnise marriage ceremonies after proper counselling with the bride and bridegroom in accordance with the stipulated laws of the Church and state. The pastor conducts home visits of members in the community, the imprisoned, aged, the sick and those in dire need. According to Patterson (1990:270) 'Pastors keep all confidential evidence inviolate, including confessional declarations except in cases were obligatory reporting is prescribed by the civil law'. It is also the duty of the United Methodist pastor to perform the sacrament of the Lord's Supper and baptism according to Christ's command.

Pastors teach parents and guardians before baptising children or infants, instructing them to teach their children at home concerning the importance of baptism. They encourage renewal of baptismal vows and reaffirmation of baptismal covenant at different stages in life. The pastor urges members to be baptised at early childhood or infant stages to make affirmation of faith, after order, so as to become professing members of the church. It is the duty of the pastor to explain the meaning of Eucharist and urge constant involvement so as to increase holiness and faith. Pastors are involved in the selection and training of lay members who are to serve the Holy Communion (Patterson 1990:271). The pastor embodies Jesus's teachings in servant ministries and servant leadership. He or she also gives conscientious pastoral guidance in administering the congregants for the transformation of the world. It is within the pastor's responsibilities as well to mould the body of Christ into a giving, sharing community and expanding the ministry. It is also the responsibility of the pastor to be involved in ecumenical, religious and community concerns, and to exhort members to participate in prayer retreats. A good pastor labours for the unity of purpose amongst members and should teach against heresy or false teaching.

Pastors are obliged to first obtain a written letter from the superintendent permitting them to embark on evangelistic activities (Mushishi 2010:45). A pastor shall not arbitrarily order a pastoral charge, a new local church or mission congregation without the permission of the resident bishop. Pastors are not allowed to hold a religious service outside their jurisdiction or boundary.

\section{Responsibilities of district superintendents}

District superintendents are commissioned by the cabinet and bishop. They are tasked to duties of supervision and oversight within the episcopal area and the district. Before the selection and appointment of a district superintendent, the resident bishop works in liaison with the committee on superintendency and cabinet for new assignments. According to Bondo (2011:38), the district superintendent is the overseer of the entire ministry of churches in communities of the district in the service, world and the missions of witness. The superintendent gives preference and effort to spiritual leadership and the scheduling of time for appropriate ministries. They give pastoral encouragement, support and supervision to the clergy and to lay leadership in the district. The district superintendent encourages spiritual, professional and personal growth to members. They also promote personal dedication to the instruction of impartiality amongst the members of the church. District superintendents support 
model and promote generous Christian living with special emphasis on the biblical principles of giving.

The district superintendent should initiate good working relationships within clergy, district lay leaders, pastor parish relations committees and other lay leaders to foster synergies of various ministries in the district. The superintendent endeavours to be connected to the entire district through the use of charge conferences, revivals, spiritual formation activities and congregational studies. The district superintendent should also live an exemplary life of spiritual leadership by participating in spiritual formations. He or she shall also be involved in both corporate and personal worship, as well as devotional practices including participation in the sacraments (Machinga 2011:23). In the structure of their administrative duties, superintendents will provide care, counsel and support to pastors pertaining issues influencing successful ministry. Furthermore, district superintendents should urge the formation of compact communities and groupings amongst both laity and clergy in the district. He or she shall get electronic or written documents of the pastors' current ministry work, spiritual practices, further education and strategic documents for future plans. The superintendent keeps relevant documents of all pastors appointed to parishes in the district and records of the church property, tangible assets and endowments of the United Methodist Church. According to Kurewa (2011:408), the 'district superintendent shall work in liaison with the bishop and cabinet in developing strategic plans for the appointment of clergy in the district, including restructuring of pastoral charges'. The superintendent is mandated to decide and interpret all matters of discipline and constitution of the church, liable to change by the annual conference.

The district superintendent should collaborate with the board on ordained ministry in the endeavour to arrange or provide guidance in consultation with pastors during the period of termination or change in membership. The superintendent should work on the delight of the resident bishop to presume relevant duties as decided by the bishop. According to Mushishi (2010), the:

$[N]$ ormal term for a district superintendent should be up to six years, but this may be extended up to eight years at the discretion of the bishop, in consultation with the committee on superintendency and the cabinet. (p. 47)

District superintendents are appointed and allotted to districts and they are also given conference wide duties. They are members of the annual conference who are commissioned to pastoral charges. In other words, they become members of the cabinet first before they are consequently allotted by the resident bishop to serve in districts. According to Patterson (1990:274), the 'cabinet under the guidance of the bishop is the articulation of superintending leadership in and through the annual conference'. The cabinet is anticipated to be the mouthpiece of the conference on the temporal and spiritual matters that emanate within the region surrounded by the conference. The district superintendents are obliged to attend cabinet meetings where they give progress reports of their respective districts. In pursuance of generating purposeful direction, the cabinet meets at stipulated periods. The cabinet is tasked with overseeing the temporal and spiritual matters of the church. The cabinet executes its duties in cooperation and consultation with other committees and boards of the entire church (Nhiwatiwa 1997:41).

The district superintendent shall develop with the pastor, the parish relations committee profiles of all pastors that contain the characteristics, requirements and chances for ministry of the parish compatible with church doctrine. These profiles shall be revisited yearly and reviewed when necessary. These profiles contain the general situation of a congregation taking into account a particular setting, financial condition, size, history and the quality of lay leadership (Kirby 2000:90). Also included in the profiles are functions and qualities of pastoral leadership required to fulfil mission, goals and vital needs of the congregants. The district superintendent should formulate with the pastor profiles containing the pastor's professional experience, talents, expectations, evidence of the grace of God, the concerns and needs of the pastor's family and spouse on an annual basis. These profiles should be updated every year and reviewed when necessary, to include spiritual and personal sensibility. The profiles also contain the experience in further education, reports of performance, theological stance and work experience. Haynes (2010:66) asserted that profiles shall also reflect the abilities and skills of a particular pastor looking at church administrative skills, worship or liturgy, evangelism and nurturing, preaching, teaching, leadership development, promoting and interpreting the connectional giving system. According to Haynes (2010:66), a 'leader should have the ability to work in cooperation, counselling, group work, self-evaluation and other relational skills'. The superintendent should establish community profiles together with the committee on pastor parish relations and pastor. The relevant data on these profiles should encompass state, neighbourhood and national statistical information. Also included are the general demographic data, trends, sex, age and ethnic proportion of the said society. The profile also projects other economical, historical, political, sociological and non-denominational aspects of the community neighbouring the church. The profiles are necessary especially during the appointment making process (Harmon 1974:102).

\section{Responsibilities of bishops in United Methodist Church}

The United Methodist Church bishop has a responsibility of leading and exercising a general oversight of spiritual and leadership matters of the church. He or she has the duty to encourage members to fulfil the mission of the church, which is to transmit, teach, proclaim and guard individually and corporately the faith as revealed in tradition and scripture. Bishops are graced by the Holy Spirit to translate faith prophetically and evangelically. The bishops derive their authority from the office rather than personal ability or charisma (Puskas 1989:239). They also travel throughout the 
episcopal area executing plans of action for the growth of the church. Bishops should uphold and teach the theological traditions of the church.

The bishops safeguard the theological guidelines of the church, they guarantee that there is truthful transmission of these doctrinal standards. Wesley thought that the fundamental aspect of the Christianity was disclosed through scripture, illustrated via tradition, animated through experience, and established via reason. Furthermore, scripture, tradition, reason and experience become the basis for doing theology in the United Methodist Church. According to Short (1985:77) 'the living Christ is encountered in humanity through scripture and experience'. It is the responsibility of the bishop to offer leadership skills in the pursuit of Christian unity in mission, structure and in the search for nourished interrelationships with other communities of faith. Bishops should also organise missions sanctioned by the general conference. They support and promote outreach and witnessing ministries of the entire church. The bishop supports, models and promotes benevolent Christians living with strong emphasis to the biblical teachings of giving.

Apart from the specific responsibilities, the bishop also has presidential duties. He or she presides in the jurisdictional, annual, general and central conferences (Norwood 1974:72). He or she provides general supervision for the programme of monetary operations of the annual conference. They may encompass social exploration of the work of organisations to guarantee that the church's procedures and policies are adhered to. They guarantee just procedures for laity and clergy as stipulated by the church are monitored. The bishop also establishes new districts after liaising with district superintendents and as decided by annual conference. They also ordain elders, appoint district superintendents, consecrate bishop and diaconal ministers (Ziegler 1959:101).

The appointment of clergy is made by the cabinet together with the bishop. Appointments take into account the community context, the gifts and evidence of grace in a specific pastor and unique needs of a particular charge. This implies that before appointment, the congregation and the pastor to be appointed must be consulted by the area superintendent. In fact, a concerned pastor may negotiate for consideration of a possible change in the assigned area. The change can also be requested by the pastor parish representatives, the bishop or the area superintendent. The episcopal leader and the area cabinet should contemplate all appeals for possible reassignments, gifts, evidence of grace, family needs of the pastor, and professional experience (Lee \& Sweet 1956:131). During the process of making a new appointment, the bishop and the overseer should consult with the pastor in charge concerning a particular shift in appointment, then finally the receiving committee on pastor parish relations. If it is decided by cabinet and bishop that the given determination should not take place, the procedure can be reiterated until negotiations become clear to the bishop to make the appointment. The United Methodist Church works under the itinerancy system when making appointments. It is the responsibility of the bishop to appoint local missionaries and deaconess, and to make sure that the names of the appointees are recorded in the statistical records.

Any elder is eligible to be elected into the episcopal office and commissioned to the role of servant leadership, supervision and general overseership of the church. Just like followers of Jesus Christ, bishops are sanctioned to preserve order, liturgy, faith, discipline and church doctrine. The calling and role of the episcopal leader is to exercise oversight and to provide guidance to the mission of the church, which is making disciples of all nations and the world's transformation. The foundation of principled leaders emanates from a disciplined life. The duty of the disciples is to truthfully model, lead and practise spiritual discipline. According to Patterson (1990:36), 'the bishop is to lead in private and public worship, the administration of the sacraments and in the commendation of our faith'. The duty of the bishop is to take charge of the entire congregation in claiming higher in the fulfilments of its mission and vision. The bishops lead in inspiring, equipping, discerning, strategising, evaluating and implementing the fulfilment of the objectives of the church.

The bishop plays a prophetic role, he or she is a tool for justice in a conflicted and suffering world through upholding social righteousness and tradition. The resident bishop remains the voice of the voiceless and the conscience of the people to the governing authorities of the state. The bishop a role model and urges the vision of the service and witness in the entire world through the pronouncement of the good news and eradication of the suffering of humanity. According to Patterson (1990):

The role of the bishop is to be the chief shepherd of the entire flock and thereby providing leadership towards the goal of the reconciliation and the unity of the universal church. (p. 317)

\section{Election, assignment and termination of bishops}

In central conferences, the number of episcopal leaders shall be decided based on mission's potential as sanctioned at the general conference on the guidance of the elected committee on central conference matters. The number of circuits in the area conference and the total sum of active pastors in the episcopal area should also be taken into consideration when electing bishops. It also takes into consideration the geographical size, which is measured by square kilometres and the numbers of nations and time zones. According to James (1935):

Three hundred thousand church members shall be entitled to five bishops. Bishops are nominated by delegates to the annual conference using the ballot method. The names of top three nominees shall be forwarded to the central conference for election. (p. 73)

When electing bishops, the delegates should take into consideration the comprehensiveness of the church with regard to national origins, race and sex. The central 
conference is sanctioned to determine the proportion of votes needed to legitimise bishop's election. It is also authorised that at least two-thirds of the total attendance should constitute the eligibility of an election. According to Patterson (1990:319), 'the bishops' consecration should be conducted at the venue of the conference during its proceedings and time denoted by the conference'. The consecration service has to be attended by leaders from other central conferences and representatives from other Christian fellowships.

The episcopacy committee of the judicial conference in liaison with the council of bishops should endorse the allotment of the resident bishops to their particular places for ultimate decision by the jurisdiction conference. A bishop may be endorsed for duty to the same residence for a third quadrennial. According to Patterson (1990:320), a newly appointed bishop should be allotted to manage an area where his or her membership was recently recorded. However, by two-thirds majority vote of the jurisdictional committee, the given restriction shall not be taken into consideration. The jurisdictional and central conference committee on episcopacy, in liaison with the council of bishops, should endorse the allotment of the elected bishops to their relevant residencies for final determination by the jurisdictional and central conference.

The council of bishops in concurrence with the bishops upon the consent of the committee on episcopacy, designate a representative member to some specified global missionary responsibilities for the upkeep and welfare of the entire church. In the event that a bishop discharges episcopal duties in the episcopal jurisdiction for that term, another active bishop or retired should be nominated by the council of bishops to presume episcopal responsibilities during this transitional period. This commissioning should be revived for a second term by a two-thirds majority consensus of the council of bishops in consultation with the said episcopal leader. An open post in the episcopal area may arise upon the retirement, resignation, death, leave of absence, incapacity and judicial procedure. In the event that a bishop is removed basing on the given cases, the open post should be filled by the council of bishops in consultation with the central conference committee on episcopacy. An ordained pastor who is serving as an episcopal leader up until retirement age should have the position of a retired bishop (Hartzell 1909:102). The United Methodist Church bishops retire at the age of 68 , however on the discretion of the council of bishops the term of office may be extended up to 72 years.

When a bishop has served the episcopal office for more than 20 years under a full time appointment, he or she may seek a requisition from the central or jurisdictional conference for retirement with the prerogative of getting their accrued benefits. When a bishop also has served for eight years in the episcopal office, he or she may ask for retirement based on professional reasons and may be granted permission to retire by the episcopacy committee in consultation with the council of bishops. A bishop can be placed under retirement category in spite of age by two-thirds majority vote of the jurisdictional or central conference committee on episcopacy. This action may be initiated by negligence of duty on the part of the concerned bishop. A bishop may voluntarily resign from his or her presidential responsibilities at any moment in time. An episcopal leader can decide to resign from the episcopal office through the submission of a written letter. This letter of resignation should specify or clarify the reasons for resignation and should be submitted to the council of bishops. The council of bishops in turn take appropriate measures regarding the matters associated with the resignation.

\section{The role of laity in the fulfilment of the mission of the church}

The word laity is derived from the Greek word $\lambda \alpha$ ó $\varsigma$ meaning people. More specifically laity designates those who are not ordained ministers. The lay people have always been engrossed in a particular place and played a very critical role in the church. Proportionately, they are the majority consisting of more than $95 \%$ of the membership. They are an integral part of the church, which the church cannot do without. Laity is called upon to share in the ministry of the church (Machinga 2011:36). The mission of the United Methodist Church is to make sure that people are converted to Christianity and confess their sins. The mission emanated as a result of Jesus' words in Matthew 28:1-9:

Go yee therefore and make disciples of nations, baptising them in the name of the father, the Son and the Holy Spirit, and teaching them to obey everything that I have commanded you.

The ministry of the church develops around the mission of Jesus whose ministry is that of everlasting love. Christianity therefore is the inward and outward expression of the human mind and the vision, goal and mission of Christ by a community of Christians that demonstrates a common life of devotion, service and witness discipleship and celebration. The mission of the church today is to further the ministry of Christ through healing, teaching, preaching and reconciliation.

Lay members are important contributors in fulfilling the mission of the church. It is vital to understand that the lay people's mission and vocation is obtained from their baptism and consolidated through confirmation. The laity's work and place in the body of Christ is given to them directly by the Holy Spirit (Kraemer 1958:18).

\section{Conclusion}

In conclusion, we can say that there are striking similarities between Early Catholicism's institutions and the organisational structure of the United Methodist church. The bishops, presbyters, elders and deacons performed the same duties like that of the United Methodist Church pastors, district superintendents and bishops. The united Methodist Church shares the same apostolic succession with the early Catholic Church. The apostolic creed of the church was derived from 
Early Catholicism. Bishops acted as the custodian of faith in both; the bishops were chief administrators of the church. The lay person is also not left in this important mission of the church. It is true that each believer is endowed with spiritual gifts for use in the ministry. The laity plays a vital role in upholding membership vows, nurturing ministries, witnessing ministries and outreaching ministries. Every member of the church has the responsibility of using his or her own talents in serving the church. Some members are gifted in preaching, teaching and counselling. During the early church period, the lay people also contributed outstandingly to the spreading of the gospel. Some were great preachers and a few contributed in some benevolence activities, for example, Tabitha or Dorcas at Joppa who spent most of their time helping the needy. In both instances, clergy and laity have special roles to play, hence one can say the united Methodist church is a replica of Early Catholicism.

\section{Acknowledgements Competing interests}

The authors have declared that they have no financial or personal relationships that may have inappropriately influenced them in writing this article.

\section{Authors' contributions}

Both the authors contributed equally to the article. E.M. was supervised by E.v.E. From the thesis, E.M. and E.v.E. distilled the submitted article.

\section{Ethical considerations}

This article followed all ethical standards for research without direct contact with human or animal subjects.

\section{Funding information}

This research received no specific grant from any funding agency in the public, commercial or not-for-profit sectors.

\section{Data availability}

Data sharing is not applicable to this article as no new data were created or analysed in this study.

\section{Disclaimer}

The views and opinions are those of the authors and do not necessarily reflect the official policy or position of any affiliated agency of the author, and the publisher/s.

\section{References}

Bettenson, H., 1963, Documents of the Christian Church, Oxford University Press, London.

Bondo, N., 2011, Moving in harmony: An updated polity for the United Methodist Church in Africa, Discipleship Resources, Nashville, TN.

Dibelius, M. \& Conzelmann, H., 1776, The Pastoral Epistles, Hermeneia, Fortress Press, Minneapolis.

Dunn, J.D.G., 1990, Unity and diversity in the New Testament, SCM Press, London.

Harmon, N.B., 1974 Understanding the United Methodist Church, United Methodist Publishing, Nashville, TN.

Hartzell, J.C., 1909, The African Mission of The Episcopal Church, Abingdon Press, Nashville, TN.

Haynes, D., 2010, On the threshold of grace: Methodist fundamentals, UMR Communications, Dallas, TX.

James, I.H., 1935, Missions in Rhodesia under the Episcopal Church, Rhodesia Press, Mutare.

Kirby, I.E., 2000, The episcopacy in American Methodist, Kingswood Books, Nashville, TN.

Kraemer, H., 1958, A theology of laity, Regent College Publishing Co, Vancouver.

Kurewa, W.J.Z., 2011, Labouring side by side: The local church as the most significant arena for disciple making, Abingdon Press, Nashville.

Lee, U. \& Sweet, W.W., 1956, A short history of methodism, Abington Press, New York, NY.

Machinga, G., 2011, The time is now: Preparing candidates for baptism and confirmation in the United Methodist Church, Discipleship Resources, Nashville, TN.

Malherbe, A.J., 1986, Moral exhortation: A Greco-Roman sourcebook, Westminster Press, Philadelphia, PA.

Mushishi, C., 2010, Church administration: A devotional and motivational guide, Wipf and Stock Publishers, Eugene, OR.

Nhiwatiwa, E.K., 1997, Humble beginnings: A brief history of the United Methodist Church Zimbabwe area, Longman Publishers, Harare.

Norwood, F.A., 1974, The story of American Methodism, Abingdon Press, Nashville, TN.

Patterson, R.P., 1990, The book of discipline of The United Methodist Church, Africa Central Conference Edition, The United Methodist Publishing House, Nashville, TN.

Puskas, C.B., 1989, An introduction to the New Testament, Hendrickson Press, Peabody, MA.

Richardson, A., 1970, An introduction to the theology of the New Testament, SCM Press, London.

Schweitzer, A, 1972, Early Catholicism: A critical perspective, SCM Press, London

Short, R.H., 1985, The episcopal leadership role in The United Methodist Church, Abington Press, Nashville, TN.

Verner, D.C., 1983, The household of god: The social world of the Pastoral Epistles, Scholars Press, Sonoma, CA.

Ziegler, E.K., 1959, The village pastor, Agricultural Missions Press, New York, NY. 